\title{
EVALUASI HASIL PELAKSANAAN TEKNOLOGI MODIFIKASI CUACA (TMC) UNTUK MENGURANGI INTENSITAS CURAH HUJAN (STUDI KASUS: KEGIATAN TMC DI AREA PEMBANGUNAN PROYEK JALAN TOL BALIKPAPAN-SAMARINDA, KALIMANTAN TIMUR TAHUN 2018)
}

\author{
The Evaluation of Implementation Results from Weather Modification \\ Technology (WMT) Activity to Reduce Rainfall Intensity \\ (Case Study: The WMT Activity in Balikpapan-Samarinda Toll-Road Project \\ Area, East Kalimantan 2018)
}

\author{
M. Bayu Rizky Prayoga1)*, Rini Mariana Sibarani1), Ardila Yananto1), Samba Wirahma1), \\ Budi Harsoyo ${ }^{1)}$ \\ 1) Balai Besar Teknologi Modifikasi Cuaca - Badan Pengkajian dan Penerapan Teknologi, Gedung \\ Ir. Mohammad Soebagio, GEOSTECH (820), Kawasan PUSPIPTEK, Serpong, Tangerang Selatan \\ ${ }^{\star}$ E-mail: bayu.rizky@bppt.go.id
}

\begin{abstract}
Intisari
Penerapan Teknologi Modifikasi Cuaca (TMC) di Indonesia terus mengalami perkembangan. Tidak hanya untuk menambah curah hujan, belakangan TMC kerap dijadikan solusi yang menjanjikan untuk mengurangi curah hujan si suatu daerah. Melalui konsep Metode Kompetisi dan Metode Jumping Process, curah hujan di suatu daerah dapat dikurangi intensitasnya. Penerapan TMC untuk mengurangi curah hujan pernah diterapkan di area proyek pembangunan jalan tolBalikpapan-Samarinda, Kalimantan Timur. Melalui evaluasi terhadap curah hujan secara spasial maupun temporal, dapat diketahui indikasi pengurangan curah hujan di wilayah tersebut. Secara spasial, aktivitas TMC mampu meredistribusi hujan di daerah upwind sehingga area pembangunan tol mendapatkan curah hujan yang lebih kecil. Menggunakan pendekatan statistik dengan membandingkan curah hujan prediksi dan curah hujan aktual, didapatkan estimasi tingkat pengurangan curah hujan selama kegiatan TMC berlangsung di kisaran nilai $40 \%$.
\end{abstract}

Kata Kunci : Evaluasi, Modifikasi Cuaca, Intensitas Curah Hujan, Pengurangan Curah Hujan.

\begin{abstract}
The application of Weather Modification Technology (WMT) in Indonesia continues to develop. Not only to increase rainfall, but WMT is often used as a promising solution to reduce rainfall in an area. Through the concept of the Competition Method and the Jumping Process Method, the intensity of rainfall in an area can be reduced. The application of WMT to reduce rainfall has been applied in the project area of the Balikpapan-Samarinda toll road construction, East Kalimantan. Through the evaluation of rainfall spatially and temporally, it can be seen as an indication of a reduction in rainfall in the region. Spatially, WMT activity can redistribute rainfall in the upwind area so that the toll road construction area gets smaller rainfall. Using a statistical approach by comparing predicted rainfall and actual rainfall, an estimated level of rainfall reduction during the TMC activity takes place in the range of $40 \%$.
\end{abstract}

Keywords: Evaluation, Weather Modification, Rainfall Intensity, Rain Reduction.

\section{PENDAHULUAN}

Proyek pembangunan jalan tol BalikpapanSamarinda di Provinsi Kalimantan Timur merupakan salah satu Proyek Strategis Nasional yang masuk dalam daftar 37 Proyek Prioritas, sebagaimana tertuang dalam Instruksi Presiden Republik Indonesia Nomor 1 Tahun 2016 dan Peraturan Presiden Republik Indonesia Nomor 3
Tahun 2016. Secara administratif, lokasi proyek ini berada di wilayah Kabupaten Tenggarong, Kalimantan Timur. Proyek jalan tol sepanjang 99,35 km yang menghubungkan kota Balikpapan dan kota Samarinda ini nantinya akan mempersingkat waktu tempuh dari Balikpapan ke Samarinda dari 3 jam menjadi 1 jam perjalanan.

Proyek pembangunan jalan tol BalikpapanSamarinda oleh Presiden Joko Widodo ditargetkan dapat selesai pada Desember 2018, 
sementara progress pelaksanaan konstruksi proyek per bulan September 2017 baru mencapai sekitar 25,92 persen. Salah satu kendala yang menghambat pelaksanaan proyek ini adalah faktor tingginya curah hujan di wilayah yang mencakup areal proyek.

Atas dasar pertimbangan masih tingginya curah hujan di wilayah Kalimantan Timur yang berpotensi mengurangi efektivitas pekerjaan proyek jalan tol Balikpapan-Samarinda, PT Wijaya Karya (Persero) Tbk selaku pelaksana proyek membutuhkan upaya pengendalian cuaca di kawasan yang menjadi area proyek pembangunan jalan tol Balikpapan-Samarinda, khususnya Seksi 2, 3, dan 4 guna mempercepat dan memperlancar pembangunan jalan tol selama puncak musim hujan. Oleh karena itu, PT Wijaya Karya (Persero) Tbk kemudian meminta bantuan kepada Badan Pengkajian dan Penerapan Teknologi (BPPT) untuk melakukan modifikasi cuaca dalam rangka mengurangi intensitas curah hujan di area proyek. Kegiatan itu sendiri dilakukan selama 20 hari kegiatan pada periode 19 Januari - 7 Februari 2018.

Berbekal beberapa pengalaman kegiatan

TMC untuk mengurangi intensitas curah hujan yang pernah dilakukan BPPT (SEA GAMES 2011, Banjir Jakarta 2013 \& 2014), maka konsep pengurangan intensitas curah hujan yang digunakan yaitu menggunakan dua metode yaitu metode kompetisi dan metode jumping process. Metode mekanisme persaingan (competition mechanism method) dilakukan dengan cara menebar partikel berukuran sangat halus dari hasil pembakaran bahan semai berbentuk padat (flare) maupun larutan $(\mathrm{CaCl} 2)$ yang dilepaskan dari sejumlah Ground Base Generator yang ditempatkan di sejumlah lokasi dengan tujuan untuk mengganggu pertumbuhan awan hujan di dalam wilayah target (Seto, et al., 2013; Purwadi \& Seto, 2014). Sementara metode mekanisme proses lompatan (jumping process method) dilakukan dengan menaburkan bahan semai dari pesawat ke dalam awan-awan di daerah upwind yang berpotensi menjadi hujan di wilayah target (Bruintjes et al., 2004; Bruintjes et al., 2012). Tujuannya adalah untuk mempercepat proses hujan pada awan - awan Cumulus di daerah upwind yang terpantau akan bergerak masuk ke arah wilayah target (DeFelice et al., 2014). Jadi, sebelum awan - awan tersebut tumbuh semakin besar dan berpotensi menyebabkan hujan di wilayah target, kandungan uap air di dalam awan tersebut dijatuhkan lebih awal untuk menjadi hujan di luar target. Dengan demikian, suplai masa udara yang pada akhirnya melintas di atas wilayah target sudah tidak lagi banyak mengandung uap air dan tidak terjadi hujan.

Bruintjes (1999) menyebutkan bahwa evaluasi hasil kegiatan modifikasi dapat dilakukan dalam dua metode pendekatan, yaitu secara statistik dan secara fisik. Selain itu, contoh evaluasi hasil kegiatan modifikasi secara statistik dengan menggunakan data curah hujan adalah penelitian yang dilakukan oleh Morrison et al. (2009) terhadap serangkaian kegiatan modifikasi cuaca yang dilakukan di Tasmania dan oleh Silverman (2010) di daerah pegunungan Sierra Nevada. Evaluasi secara statistik juga pernah dilakukan Breed et al. (2014), Geresdi et al. (2017), dan Rasmussen et al. (2018) terhadap pemodelan pilot project aktivitas modifikasi cuaca di wilayah Wyoming. Lebih lanjut, beberapa metode evaluasi untuk mengetahui hasil TMC di Indonesia sebelumnya juga pernah dilakukan oleh Nugroho (2002) dan Harsoyo et al. (2013), di antaranya menggunakan metode Target Only, TargetControl, dan Double Ratio.

Tulisan ini akan membahas mengenai hasil evaluasi pelaksanaan TMC untuk mengurangi intensitas curah hujan di area proyek pembangunan tol Balikpapan-Samarinda. Selain itu, tulisan ini juga berusaha melakukan pendekatan secara statistik untuk mengetahui tingkat pengurangan curah hujan selama kegiatan TMC dioperasikan.

\section{METODE}

Wilayah penelitian adalah area kerja pelaksanaan TMC untuk mengurangi intensitas curah hujan di area proyek pembangunan jalan tol Balikpapan-Samarinda. Secara khusus, segmen jalan tol Balikpapan-Samarinda yang menjadi target utama kegiatan adalah Segmen 2, 3 , dan 4. Wilayah penelitian seperti yang ditunjukkan pada Gambar 1 berikut.

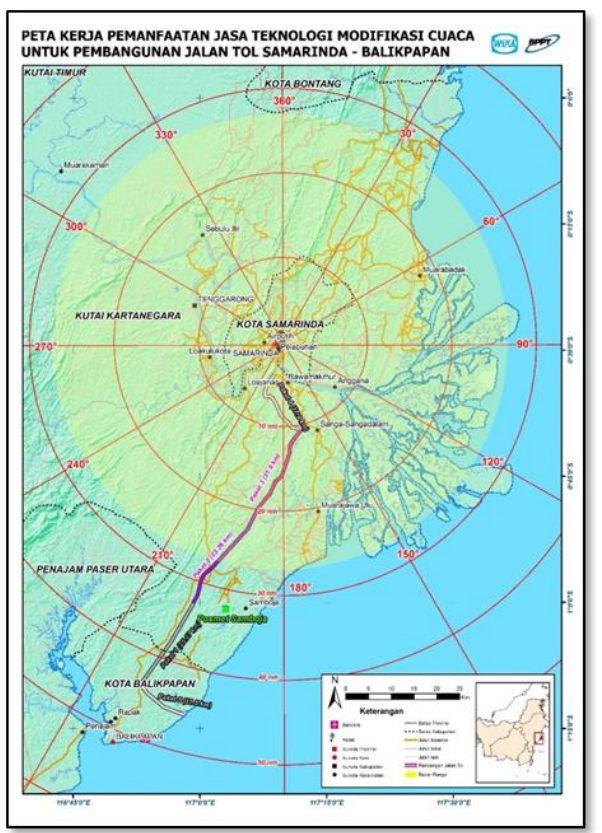

Gambar 1. Daerah target operasi redistribusi hujan (Jalan tol ditandai dengan garis tebal berwarna ungu). 
Untuk keperluan evaluasi hasil pengurangan curah hujan di area kerja, maka digunakan data curah hujan aktual yang bersumber dari JAXA TRMM dengan resolusi spasial $0.1^{\circ} \times 0.1^{\circ}$ dan resolusi temporal satu jam. Sebagai pembanding untuk membantu melakukan evaluasi hasil pengurangan curah hujan, maka digunakan data prediksi curah hujan Global Forecast System (GFS) untuk masingmasing segmen jalan tol.

Untuk mengetahui tingkat pengurangan curah hujan, maka data curah hujan yang akan dibandingkan merupakan curah hujan pada interval waktu 10.00-18.00 WITA. Pemilihan rentang waktu tersebut dimaksudkan untuk mengetahui pengaruh penerapan Teknologi Modifikasi Cuaca di wilayah target, di mana pada umumnya aktivitas penerbangan penyemaian awan untuk kepentingan redistribusi curah hujan berlangsung pada selang waktu 09.00 WITA hingga sore hari (17.00 WITA). Pada tulisan ini juga dibandingkan intensitas curah hujan selama 24 jam dan curah hujan selama jam operasional kegiatan TMC.

Hasil perbandingan antara curah hujan aktual dan curah hujan prediksi akan membantu mengetahui seberapa besar dampak TMC terhadap upaya pengurangan curah hujan di area kerja. Selain membandingkan antara curah hujan aktual dan prediksi, dilakukan pula analisis secara spasial terkait perbedaan curah hujan di area target dan daerah sekitarnya yang menjadi wilayah penyemaian awan.

\section{HASIL DAN PEMBAHASAN}

\subsection{Strategi Penyemaian Awan untuk Redistribusi Curah Hujan}

Dalam paradigma redistribusi curah hujan yang bertujuan untuk mengurangi curah hujan di suatu daerah, maka angin memegang peranan yang sangat penting. Massa udara yang bergerak selalu mengikuti pola arah angin. Sehingga awan yang berpotensi menjadi hujan, pergerakannya juga ditentukan oleh faktor arah dan kecepatan angin.

Gambar 2 menunjukkan arah dan kecepatan angin di lapisan $850 \mathrm{mb}$ pada tiga segmen jalan tol. Secara umum angin permukaan di wilayah Kalimantan Timur dan sekitarnya bertiup dari Barat Daya - Barat Laut. Angin pada level ketinggian $850 \mathrm{mb}$ di sepanjang area pembangunan jalan tol BalikpapanSamarinda dominan bertiup dari Barat Daya hingga Barat Laut dengan kecepatan 1-7 m/s. Pada awal Februari 2018 angin $850 \mathrm{mb}$ bertiup dari Selatan - Utara dengan kecepatan 1-4 m/s. Hal ini mengakibatkan selama kegiatan suplai uap air dominan berasal dari Barat Daya hingga Barat laut.

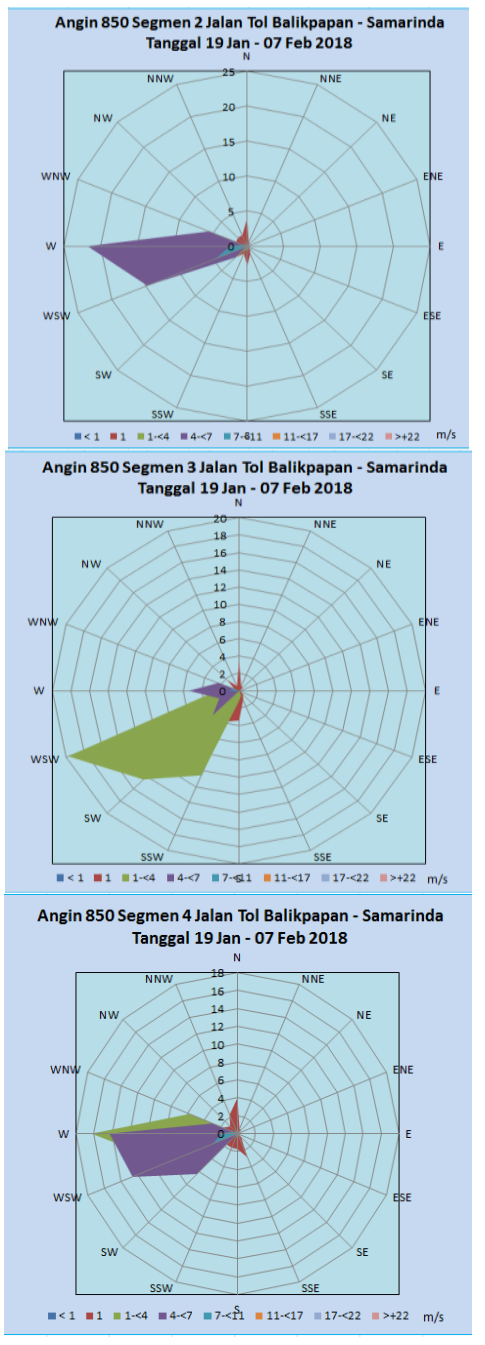

Gambar 2. Kecepatan dan Arah Angin pada ketinggian $850 \mathrm{mb}$ di ketiga Segmen jalan tol pada tanggal 19 Januari - 07 Februari 2018.

(Sumber: NOAA).

Pola angin di wilayah target yang dominan bergerak dari Barat Daya - Barat Laut berpengaruh terhadap strategi penyemaian awan TMC. Kondisi tersebut membuat massa udara dalam bentuk awan terbawa bergerak ke arah Timur Laut - Tenggara dan berpotensi menjadi hujan di area pembangunan jalan tol BalikpapanSamarinda, khususnya Segmen 2, 3 dan 4.

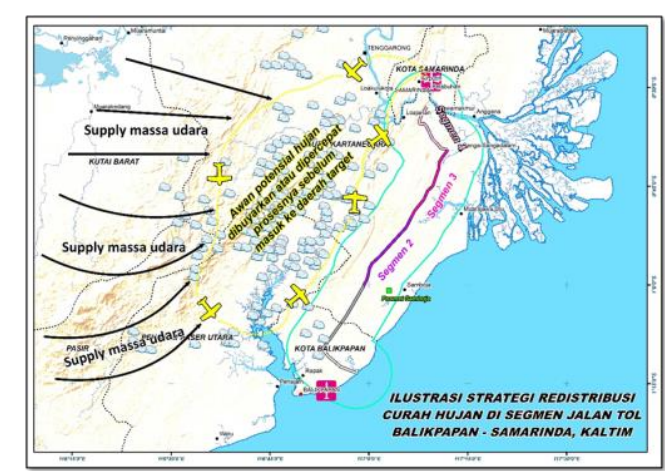

Gambar 3. Ilustrasi strategi redistribusi curah hujan yang diterapkan di area pembangunan jalan tol Balikpapan-Samarinda. 
Gambar 3 memberikan ilustrasi strategi operasi modifikasi cuaca untuk meredistribusi curah hujan di area pembangunan jalan tol Balikpapan-Samarinda. Penerbangan untuk penyemaian awan yang dilakukan pada operasi TMC di wilayah target difokuskan untuk membuyarkan awan dengan metode Jumping Process yang bertujuan untuk mempercepat proses fisik di dalam awan sehingga menjadi hujan sebelum memasuki wilayah target. Strategi tersebut dilakukan tergantung pada beberapa kondisi atmosfer di wilayah target.

\subsection{Distribusi Spasial Curah Hujan}

Selama periode pelaksanaan TMC di area pembangunan jalan tol Balikpapan-Samarinda, penyemaian awan dominan dilakukan di daerah upwind dari jalan tol. Hal tersebut bertujuan untuk mengurangi potensi hujan yang terjadi di jalan tol Segmen 2, 3 dan 4. Setelah dilakukan aktivitas modifikasi cuaca, dapat dilakukan evaluasi keberhasilan redistribusi curah hujan di wilayah target. Salah satunya, dengan membandingkan akumulasi curah hujan selama periode kegiatan secara spasial.

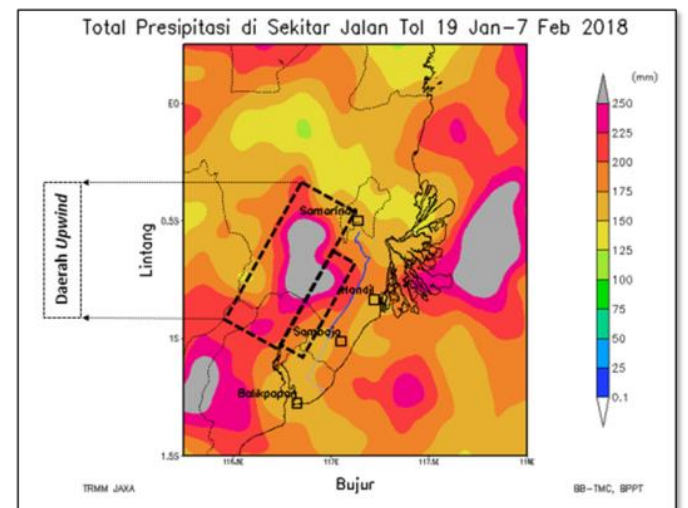

Gambar 4. Total presipitasi di sekitar jalan tol selama periode pelaksanaan TMC.

Gambar 4 menyajikan hasil monitoring hujan secara spasial. Data yang digunakan merupakan monitoring hujan yang terpantau oleh satelit Tropical Rainfall Measuring Mission (TRMM) JAXA. Pada Gambar 4 dapat diamati bahwa akumulasi curah hujan di bagian Barat yang merupakan daerah upwind dari jalan tol (jalan tol ditandai dengan garis biru) lebih besar dibandingkan di bagian Timur atau bahkan di sepanjang jalan tol Segmen 2, 3 dan 4. Akumulasi curah hujan di bagian Barat jalan tol selama periode 19 Januari-7 Februari bernilai $200 \mathrm{~mm}$ hingga lebih dari $250 \mathrm{~mm}$. Sedangkan akumulasi nilai curah hujan di sepanjang jalan tol Segmen 2, 3 dan 4 hingga bagian Timurnya (daerah downwind) mempunyai kisaran akumulasi yang lebih kecil, yaitu sebesar 125 $\mathrm{mm}$ hingga $175 \mathrm{~mm}$.

Akumulasi curah hujan di bagian Barat yang lebih tinggi mempunyai kecocokan secara spasial dengan distribusi lokasi penyemaian awan untuk meredistribusi curah hujan di daerah target. Kondisi tersebut bisa menjadi salah satu indikasi bahwa kegiatan Teknologi Modifikasi Cuaca yang diterapkan untuk meredistribusi curah hujan di Segmen 2, 3 dan 4 jalan tol Balikpapan-Samarinda cukup memberikan dampak dalam hal pengurangan curah hujan di daerah target.

\subsection{Perbandingan Curah Hujan Per- Jam}

Kegiatan penyemaian awan TMC dengan menggunakan wahana pesawat memiliki keterbatasan. Keterbatasan yang paling menonjol adalah ketidakmampuan TMC menggunakan pesawat terbang untuk dioperasikan pada malam hari. Unsur keselamatan penerbangan dan minimnya kemampuan observasi visual untuk mengamati awan pada malam hari menjadi beberapa faktor yang membuat TMC sulit dioperasikan pada malam hari.

Keterbatasan tersebut berpengaruh terhadap hasil TMC pada kegiatan ini. Gambar 5 menunjukkan intensitas curah hujan harian (total $24 \mathrm{jam} / \mathrm{hari}$ ) di setiap segmen jalan tol selama periode kegiatan TMC. Selama 16 hari kegiatan TMC, curah hujan yang terjadi di setiap segmen jalan tol memiliki intensitas ringan hingga sedang ( $<20 \mathrm{~mm} /$ hari), sedangkan dalam 4 hari kegiatan lainnya terjadi hujan dengan intensitas cukup lebat (>20 mm/hari).

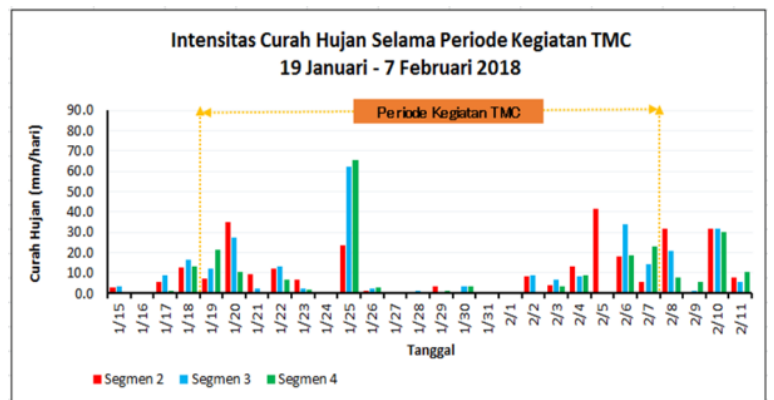

Gambar 5. Intensitas curah hujan harian (24 jam) di setiap segmen jalan tol selama periode kegiatan TMC.

Jika kita hanya mengacu pada hasil grafik hujan harian seperti pada Gambar 5, maka bisa dikatakan bahwa TMC tidak menjamin hujan dapat dikurangi. Terbukti, dengan mengacu pada data hujan selama 24 jam pada periode kegiatan, selama pelaksanaan TMC tetap terjadi hujan dengan intensitas berkisar 10-20 mm. Namun setelah dilakukan analisis lebih lanjut, dengan hanya menghitung curah hujan pada jam operasional TMC $(10.00-18.00$ WITA), didapatkan hasil yang mengindikasikan adanya pengurangan curah hujan selama rentang waktu tersebut. 


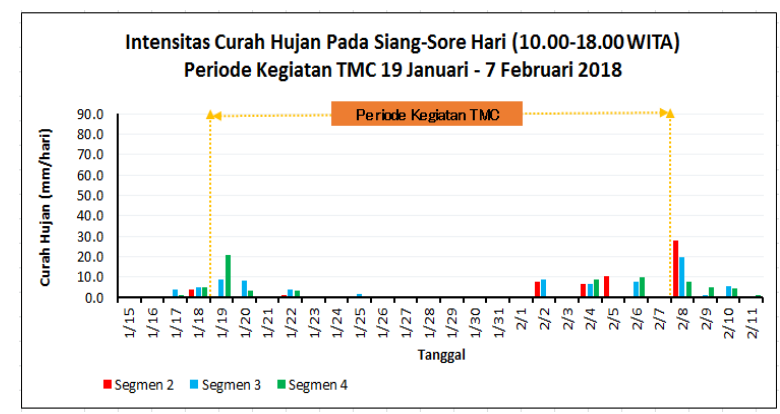

Gambar 6. Intensitas curah hujan pada siang hingga sore hari (10.00-18.00 WITA) di setiap segmen jalan tol selama periode kegiatan TMC.

Gambar 6 merepresentasikan intensitas curah hujan pada siang hingga sore hari (10.0018.00 WITA) di setiap segmen jalan tol selama periode kegiatan TMC. Berdasarkan gambar tersebut dapat diketahui bahwa Intensitas curah hujan pada siang-sore hari di area jalan tol secara umum menunjukkan nilai yang tidak signifikan.

Selama periode kegiatan TMC, curah hujan pada siang-sore hari cenderung bisa dikurangi. Hal ini sesuai dengan waktu kegiatan penerbangan penyemaian awan di daerah target yang hanya dapat diksanakan dari siang hingga sore hari.

\subsection{Perbandingan Prediksi Intensitas Curah Hujan dan Curah Hujan Aktual}

Perbandingan antara prediksi dan nilai aktual dari curah hujan dilakukan untuk mengetahui tingkat keberhasilan redistribusi curah hujan di area pembangunan jalan tol Balikpapan-Samarinda. Curah hujan yang dibandingkan merupakan curah hujan pada interval waktu 10.00-18.00 WITA. Pemilihan rentang waktu tersebut dimaksudkan untuk mengetahui pengaruh penerapan TMC di wilayah target, di mana pada umumnya aktivitas penerbangan penyemaian awan untuk kepentingan redistribusi curah hujan berlangsung pada selang waktu 09.00 WITA hingga sore hari (17.00 WITA). Tabel 1 berikut menunjukkan nilai curah hujan prediksi dan curah hujan aktual pada masing-masing segmen jalan tol.

Tabel 1. Perbandingan Curah Hujan Prediksi dan Curah Hujan Aktual Pada Tiap Segmen Jalan.

\begin{tabular}{|c|c|c|c|c|c|c|c|}
\hline \multirow{2}{*}{ Tanggal } & \multicolumn{3}{|c|}{ Prediksi Intensitas } & \multicolumn{3}{|c|}{ Curah Hujan Aktual } & \multirow{2}{*}{ Area Penyemaian Awan } \\
\hline & Seg. 2 & \begin{tabular}{|l|} 
Seg. 3 \\
\end{tabular} & \begin{tabular}{|l|} 
Seg. 4 \\
\end{tabular} & Seg. 2 & Seg. 3 & Seg. 4 & \\
\hline 1-Jan & 1.4 & 1.6 & \begin{tabular}{|l|}
1.8 \\
\end{tabular} & 0.0 & 0.3 & \begin{tabular}{|l|}
0.2 \\
\end{tabular} & \multirow{18}{*}{ Sebelum TMC } \\
\hline 2-Jan & 16.1 & 14.8 & 13.6 & 2.3 & 0.1 & 0.2 & \\
\hline 3 -Jan & 0.3 & 0.4 & 0.5 & 0.0 & 1.5 & 0.1 & \\
\hline 4-Jan & 3.4 & 5.0 & 6.7 & 4.5 & 16.7 & 13.4 & \\
\hline 5 -Jan & 14.2 & 14.1 & 14.1 & 0.0 & 0.8 & 1.7 & \\
\hline $6-\sqrt{\text { an }}$ & 11.0 & 11.3 & 11.5 & 25.7 & 47.1 & 70.2 & \\
\hline 7-Jan & 1.0 & 1.8 & 2.6 & 0.2 & 0.0 & 0.0 & \\
\hline 8 -Jan & 4.7 & 5.4 & 6.1 & 0.0 & 0.2 & 0.0 & \\
\hline 9-Jan & 3.4 & 3.3 & 3.2 & 0.0 & 0.1 & 0.0 & \\
\hline 10-Jan & 2.0 & 2.6 & 3.2 & 0.0 & 0.0 & 0.0 & \\
\hline 11-Jan & 17.3 & 17.5 & 17.7 & 2.2 & 1.4 & 1.6 & \\
\hline 12-Jan & 1.9 & 1.6 & 1.3 & 3.7 & 7.9 & 6.5 & \\
\hline 13-Jan & 0.3 & 0.2 & 02 & 0.0 & 0.0 & 6.2 & \\
\hline 14-Jan & 5.5 & 5.2 & 4.9 & 0.4 & 0.0 & 0.0 & \\
\hline 15-Jan & 0.0 & 0.0 & 0.0 & 0.1 & 0.2 & 0.2 & \\
\hline 16-Jan & 0.0 & 0.0 & 0.0 & 0.0 & 0.0 & 0.0 & \\
\hline 17-Jan & 3.5 & 5.0 & 1.5 & 0.0 & 4.1 & 1.0 & \\
\hline 18-Jan & 0.9 & 0.3 & 2.9 & 4.2 & 5.1 & 5.3 & \\
\hline 19-Jan & 9.9 & 6.9 & 7.8 & 0.5 & 8.6 & 21.0 & Daerah Barat dari Segmen 2 dan 3 \\
\hline 20 -Jan & 2.2 & 5.3 & 3.9 & 0.4 & 8.6 & 3.5 & Daerah Barat dari Segmen 2 dan 3 \\
\hline 21-Jan & 0.0 & 4.9 & 0.0 & 0.0 & 0.0 & 0.0 & Daerah Barat dari Segmen 2, 3 dan 4 \\
\hline 22-Jan & 0.0 & 1.9 & 0.0 & 1.4 & 3.9 & 3.5 & Daerah Barat dari Segmen 2 dan 3 \\
\hline 23-Jan & 4.0 & 3.8 & 4.9 & 0.4 & 0.5 & 0.4 & Daerah Barat dari Segmen 2, 3 dan 4 \\
\hline 24-Jan & 0.2 & 2.2 & 3.6 & 0.1 & 0.4 & 0.2 & Daerah Barat dari Segmen 2, 3 dan 4 \\
\hline 25-Jan & 6.3 & 3.6 & 5.0 & 0.0 & 2.0 & 0.0 & Daerah Barat Laut dari Segmen 4 dan Barat Segmen 3 \\
\hline 26-Jan & 0.0 & 0.0 & 0.0 & 0.0 & 0.0 & 0.2 & Daerah Barat Laut dari Segmen 4 dan Barat Daya-Barat Segmen 2 \\
\hline 27-Jan & 0.2 & 2.1 & 0.5 & 0.0 & 0.0 & 0.0 & Daerah Barat dari Segmen 2, 3 dan 4 \\
\hline 28-Jan & 6.3 & 0.9 & 7.5 & 0.0 & 0.0 & 0.0 & Daerah Barat dari Segmen 2, 3 dan 4 serta Barat-Utara Segmen 4 \\
\hline 29-Jan & 0.2 & 4.1 & 0.6 & 0.0 & 0.0 & 0.0 & Tidak dilakukan penerbangan karena masalah teknis pesawat \\
\hline 30 -Jan & 1.6 & 2.8 & 6.2 & 0.0 & 0.0 & 0.0 & Tidak dilakukan penerbangan karena masalah teknis pesawat \\
\hline 31-Jan & 0.9 & 2.2 & 0.7 & 0.0 & 0.0 & 0.0 & Daerah Barat-Barat Laut dari Segmen 4 \\
\hline 1-Feb & 12.6 & 3.9 & 12.4 & 0.0 & 0.0 & 0.0 & Daerah Barat dari Segmen 2, 3 dan 4 \\
\hline 2-Feb & 1.6 & 1.2 & 2.7 & 7.9 & 8.7 & 0.0 & Tidak dilakukan penerbangan karena masalah teknis pesawat \\
\hline $3-\mathrm{Feb}$ & 4.4 & 4.3 & 5.9 & 0.0 & 0.0 & 0.0 & Tidak dilakukan penerbangan karena masalah teknis pesawat \\
\hline 4-Feb & 2.8 & 0.0 & 5.2 & 6.6 & 6.7 & 9.1 & Daerah Barat Daya-Barat dari Segmen 2,3 dan 4 \\
\hline 5-Feb & 14.1 & 7.6 & 15.2 & 10.7 & 0.0 & 0.0 & Daerah Barat Daya-Barat dari Segmen 2,3 dan 4 \\
\hline $6-\mathrm{Feb}$ & 5.2 & 8.2 & 4.6 & 0.0 & 7.9 & 10.2 & Daerah Barat dari Segmen 2, 3 dan 4 \\
\hline 7-Feb & 9.7 & 6.8 & 8.5 & 0.7 & 0.0 & 0.0 & Daerah Barat dari Segmen 2, 3 dan 4 \\
\hline $8-\mathrm{Feb}$ & 4.5 & 2.3 & 2.4 & 25.8 & 19.7 & 7.9 & \multirow{7}{*}{ Setelah TMC } \\
\hline 9-Feb & 2.1 & 5.8 & 6.2 & 0.0 & 1.2 & 5.2 & \\
\hline $10-\mathrm{Feb}$ & 1.9 & 14.4 & 13.9 & 0.0 & 5.4 & 4.3 & \\
\hline $11-\mathrm{Feb}$ & 18.4 & 1.1 & 0.9 & 2.2 & 1.4 & 1.6 & \\
\hline 12-Feb & 1.9 & 1.3 & 2.0 & 3.7 & 7.9 & 6.5 & \\
\hline 13-Feb & 0.1 & 5.4 & 5.4 & 10.3 & 2.2 & 4.2 & \\
\hline $14-\mathrm{Feb}$ & 5.7 & 6.2 & 5.0 & 0.0 & 0.0 & 0.0 & \\
\hline
\end{tabular}


Seperti yang ditunjukkan pada Tabel 1 , secara umum nilai curah hujan aktual selama periode pelaksanaan kegiatan TMC di area pembangunan jalan tol Balikpapan-Samarinda menunjukkan nilai yang lebih kecil jika dibandingkan dengan nilai prediksi. Lebih jelasnya, Gambar 7, 8, dan 9 menunjukkan perbandingan curah hujan prediksi dan aktual pada tiap segmen secara temporal.

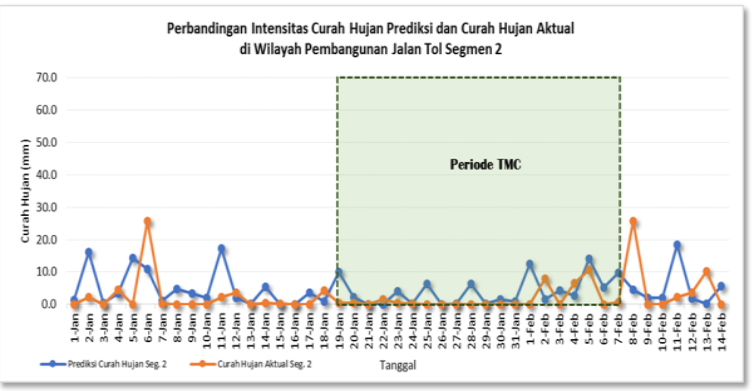

Gambar 7. Perbandingan intensitas curah hujan prediksi dan curah hujan aktual di segmen 2 .

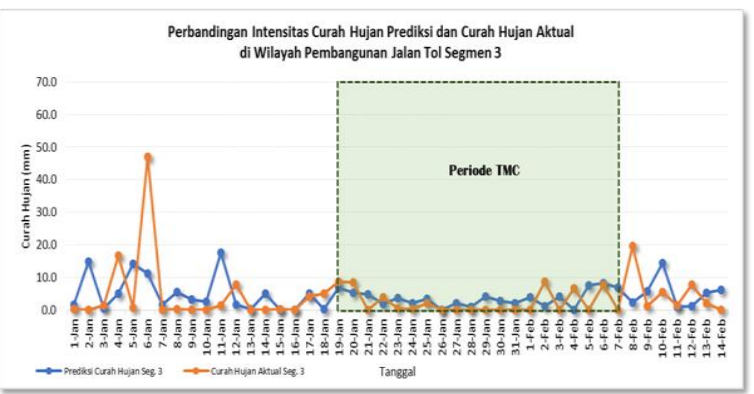

Gambar 8. Perbandingan intensitas curah hujan prediksi dan curah hujan aktual di segmen 3 .

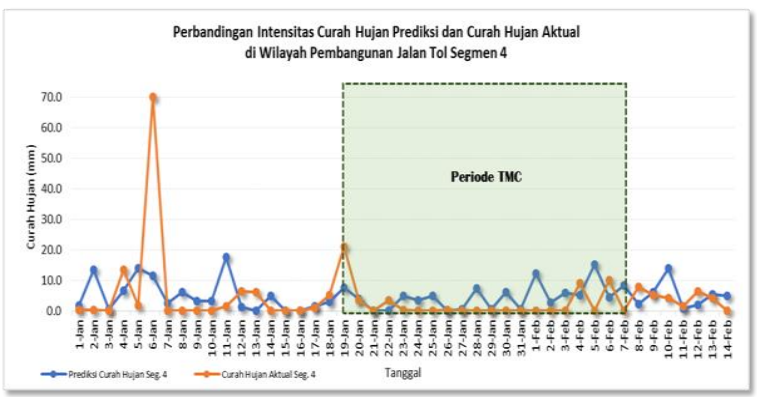

Gambar 9. Perbandingan intensitas curah hujan prediksi dan curah hujan aktual di segmen 4.

Secara keseluruhan selama periode pelaksanaan TMC, nilai curah hujan aktual di setiap segmen pembangunan jalan tol menunjukkan nilai yang cenderung lebih kecil jika dibandingkan nilai prediksi. Hal tersebut bisa menjadi salah satu indikasi hujan yang berpotensi masuk ke wilayah pembangunan jalan tol dapat teredistribusi di wilayah lainnya, sehingga intensitas curah hujan di wilayah target bisa berkurang.

Selain itu, sebagai perbandingan efek TMC pada redistribusi hujan bisa dilakukan dengan cara membandingkan intensitas hujan aktual dan intensitas hujan yang diprediksi. Berdasarkan kondisi tersebut, nampak di ketiga segmen jalan tol pada periode sebelum dan sesudah TMC memiliki kecenderungan nilai curah hujan aktual yang lebih besar jika dibandingkan dengan nilai curah hujan yang diprediksikan. Sedangkan jika melihat perbandingan pada periode pelaksanaan TMC, nampak cukup jelas bahwa nilai hujan aktual cenderung selalu lebih kecil jika dibandingkan dengan nilai curah hujan yang diprediksi. Hal itu bisa menjadi salah satu indikasi peran TMC dalam meredistribusi curah hujan di segmen pembangunan jalan tol Balikpapan-Samarinda.

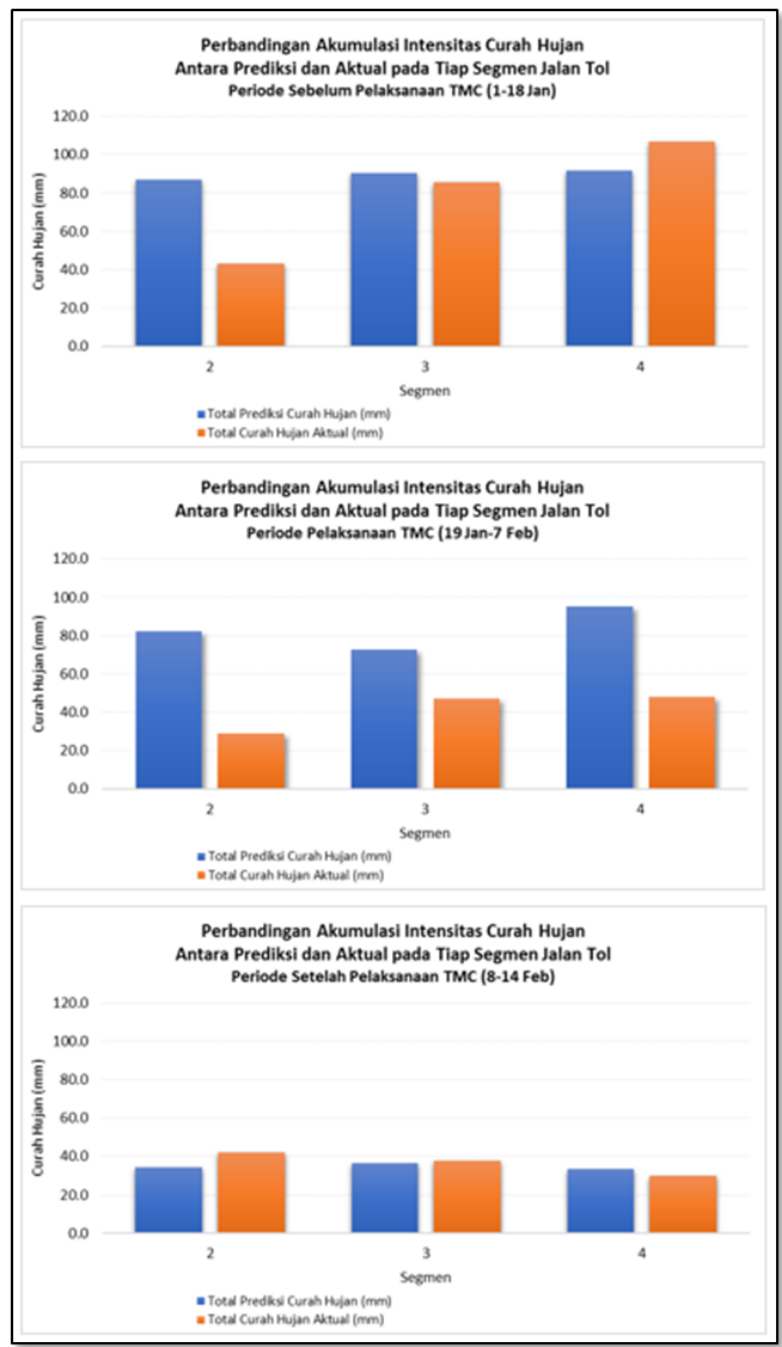

Gambar 10. Hasil perbandingan nilai intensitas curah hujan prediksi dan curah hujan Aktual.

Gambar 10 menyajikan visualisasi perbandingan curah hujan aktual dan prediksi pada masing - masing segmen jalan tol pada periode sebelum, selama, dan setelah kegiatan TMC berlangsung. Pembagian periode didasarkan pada pelaksanaan kegiatan TMC di area target di mana: Periode Sebelum TMC (1-18 Jan 2018), Periode Pelaksanaan TMC (19 Jan-7 Feb 2018) dan Periode Setelah Kegiatan TMC (8-14 Feb 2018). Pembagian periode tersebut 
dimaksudkan untuk mempermudah mengamati efek TMC terhadap redistribusi curah hujan.

Perbandingan secara periode seperti Gambar 10 dapat membantu mengamati bahwa sebelum periode kegiatan TMC, selisih akumulasi curah hujan aktual dan prediksi tidak signifikan. Hal tersebut mengindikasikan bahwa curah hujan di area pembangunan jalan tol hampir selalu bernilai persis seperti nilai prediksi pada awalnya.

Sementara kondisi berbeda dapat dilihat pada periode pelaksanaan TMC. Terdapat selisih nilai yang cukup signifikan antara curah hujan aktual dan nilai prediksi awal. Kondisi itu mengindikasikan bahwa selama kegiatan TMC berlangsung, nilai curah hujan aktual cukup dapat teredistribusi sehingga bisa dikurangi intensitasnya jika dibandingkan dengan prediksi awal.

Setelah kegiatan TMC selesai, pola perbandingan curah hujan aktual dan prediksi kembali seperti pola saat periode sebelum kegiatan TMC berlangsung. Pola tersebut menunjukkan kecenderungan nilai prediksi yang tidak terlalu berbeda jauh dibandingkan hujan aktual di area target.

Berdasarkan kondisi tersebut, maka bisa dihitung jumlah curah hujan yang terredistribusi selama pelaksanaan kegiatan TMC di wilayah target dengan mengurangi selisih hujan aktual dengan prediksinya pada saat sebelum, sesudah dan saat pelaksanaan TMC. Besar curah hujan redistribusi di wilayah target, dapat dilihat seperti pada formulasi berikut:

Curah Hujan $_{\text {redistribusi }}=\Delta A P_{\text {saat } T M C}-\Delta A P_{\text {sblm \& ssdh TMC }}$

Dimana $\triangle \mathrm{AP}_{\text {saatTMc }}$ adalah selisih hujan aktual terhadap prediksi hujannya pada saat TMC, dan $\triangle \mathrm{AP}_{\text {sblm\&ssdhTMc adalah selisih hujan }}$ aktual terhadap prediksi hujannya pada saat sebelum dan setelah TMC. Sehingga untuk dapat menentukan persentase curah hujan yang terdistribusi selama kegiatan TMC di wilayah target, dapat dihitung dengan membandingkan besar curah hujan redistribusi dengan besar prediksi hujannya, seperti pada formulasi berikut:

$\%$ Curah Hujan redistribusi $=\left(\frac{\text { Curah Hujan }_{\text {redistribusi }}}{\text { Prediksi Hujan }}\right) \%$

Gambar 11 menunjukkan data curah hujan redistribusi selama kegiatan TMC serta persentase curah hujan redistribusi di area pembangunan jalan tol berikut dengan visualisasinya.

Hasil perhitungan persentase curah hujan redistribusi pada masing-masing segmen seperti yang disajikan pada Gambar 11 menunjukkan bahwa pada umumnya intensitas curah hujan di wilayah target dapat teredistribusi hampir setengahnya. Curah hujan redistribusi sebelum dan setelah pelaksanaan TMC di segmen 2 sebesar $18,05 \mathrm{~mm}$, di segmen 3 sebesar 1,66 $\mathrm{mm}$ dan di segmen 4 terjadi penambahan hujan sebesar 5,62 $\mathrm{mm}$. Sedangkan selama kegiatan TMC Curah hujan redistribusi di segmen 2 sebesar 35,21 mm, di segmen 3 sebesar 23,76 $\mathrm{mm}$ dan segmen 4 sebesar $52,79 \mathrm{~mm}$.

Dari data hasil curah hujan redistribusi sebelum, sesudah dan selama kegiatan TMC, terlihat curah hujan redistribusi selama kegiatan TMC lebih besar dari curah hujan redistribusi pada saat sebelum dan setelah kegiatan TMC. Tingkat persentase hasil redistribusi di wilayah tersebut secara berurutan adalah sebagai berikut: Segmen 2 (42,87\%), Segmen 3 (32,68\%) dan Segmen $5(55,47 \%)$. Secara keseluruhan, maka diketahui bahwa rata-rata intensitas curah hujan di wilayah pembangunan jalan tol Balikpapan-Samarinda dapat teredistribusi sebesar $43,67 \%$ selama kegiatan TMC dilakukan.

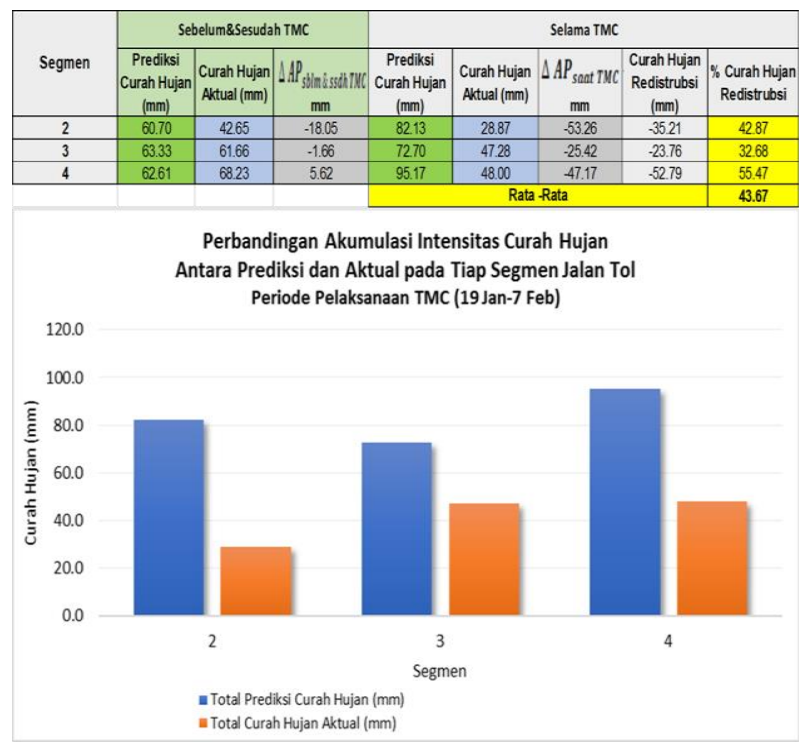

Gambar 11. Hasil perhitungan curah hujan redistribusi selama periode pelaksanaan TMC.

\section{KESIMPULAN}

Berdasarkan perbandingan dan pengolahan data curah hujan prediksi dan aktual, baik secara temporal maupun spasial, ada indikasi bahwa kegiatan TMC untuk mengurangi intensitas curah hujan di area kerja tol Balikpapan-Samarinda memberikan dampak yang cukup positif. Secara spasial, area pembangunan jalan tol Balikpapan-Samarinda Segmen 2, 3, dan 4 mendapatkan akumulasi curah hujan yang cenderung lebih kecil $(125 \mathrm{~mm}$ hingga $175 \mathrm{~mm}$ ) dibandingkan wilayah upwind yang merupakan wilayah penyemaian awan kegiatan TMC (200 mm hingga $>250 \mathrm{~mm}$ ).

Meski operasional penyemaian awan untuk redistribusi curah hujan selama kegiatan TMC tidak bisa dilakukan selama 24 jam pada tiap harinya, namun berdasarkan data curah 
hujan selama jam operasional TMC menunjukkan curah hujan yang cukup minim di area kerja. Analisis tingkat pengurangan curah hujan selama jam operasional TMC juga menunjukkan kecenderungan curah hujan selama kegiatan TMC dapat dikurangi apabila dibandingkan dengan periode sebelum maupun setelah TMC dilaksanakan.

Melalui pendekatan statistik yang dilakukan, maka didapatkan pengurangan curah hujan sekitar $40 \%$ di area kerja tol BalikpapanSamarinda selama kegiatan TMC berlangsung. Penulis menyadari bahwa pendekatan statistik yang dilakukan belum cukup komprehensif untuk memberikan angka tingkat pengurangan curah hujan secara akurat. Namun melalui berbagai pendekatan pada tulisan ini, penulis berupaya untuk menunjukkan bahwa ada indikasi pengurangan curah hujan di area target selama kegiatan TMC. Selain itu, melalui penelitian ini diharapkan akan membuka peluang untuk melakukan pengembangan metode evaluasi hasil pelaksanaan kegiatan TMC.

\section{DAFTAR PUSTAKA}

Breed, D., Rasmussen, R., Weeks, C., Boe, B., Deshler, T. (2014). Evaluating Winter Orographic Cloud Seeding: Design of the Wyoming Weather Modification Pilot Project (WWMPP). Journal of Applied Meteorology and Climatology, 53(2), 282299. doi: 10.1175/JAMC-D-13-0128.1

Bruintjes, R.T. (1999). A Review of Cloud Seeding Experiments to Enhance Precipitation and Some New Prospects. Bulletin of the American Meteorological Society. 80(5), 805-820. doi: 10.1175/1520-

0477(1999)080<0805:AROCSE>2.0.CO;2

Bruintjes, R.T., Salazar, V., Breed, D., Li, J., Buseck, P., Jensen, T., Ross, K., Piketh, S., Reid, J. (2004). Aerosol Interactions on Clouds with Emphasis on the Arabian Peninsula. $16^{\text {th }}$ Conference on Planned and Inadvertent Weather Modification. 85 AMS Annual Meeting.

Bruintjes, R.T., Salazar, V., Semeniuk, T.A., Buseck, P., Breed, D.W., Gunkelman, J. (2012). Evaluation of Hygroscopic Cloud Seeding Flares. The Journal of Weather Modification, 44(1). 69-94.

DeFelice, T.P., Golden, J., Griffith, D., Woodley, W., Rosenfeld, D., Breed, D., Solak, M., Boe, B. (2014). Extra Area Effects of Cloud
Seeding - An Updated Assessment. Atmospheric Research, 135, 193-203. doi: 10.1016/j.atmosres.2013.08.014

Geresdi, I., Xue, L., Rasmussen, R. (2017). Evaluation of Orographic Cloud Seeding Using a Bin Microphysics Scheme: TwoDimensional Approach. Journal of Applied Meteorology and Climatology, 56(5), 14431462. doi: 10.1175/JAMC-D-16-0045.1

Harsoyo, B., Haryanto, U., Seto, T.H., Tikno, S., Tukiyat., Bahri, S. (2013). Evaluasi Hasil Pelaksanaan Teknologi Modifikasi Cuaca di Jawa Barat Menggunakan Analisis Data Curah Hujan. Jurnal Sains \& Teknologi Modifikasi Cuaca, 14(2), 1-5.

Morrison, A.E., Siems, S.T., Manton, M.J., Nazarov, A. (2009). On the Analysis of a Cloud Seeding Dataset over Tasmania. Journal of Applied Meteorology and Climatology, 48(6), 1267-1280. Doi: 10.1175/2008JAMC2068.1

Nugroho, S.P. (2002). Evaluasi dan Analisis Curah Hujan sebagai Faktor Penyebab Bencana Banjir Jakarta. Jurnal Sains \& Teknologi Modifikasi Cuaca, 3(2), 91-97.

Purwadi., Seto, T.H. (2014). Desain Konseptual Ground Based Generator (GBG) Otomatis dan Konsep Operasional Berbasis Wireless Sensor Network (WSN). Jurnal Sains \& Teknologi Modifikasi Cuaca, 15(1), 9-14. doi: 10.29122/jstmc.v15i1.2651

Rasmussen, R.M., Tessendorf, S.A., Xue, L., Weeks, C., Ikeda, K., Landolt, S., Breed, D., Deshler, T., Lawrence, B. (2018). Evaluation of the Wyoming Weather Modification Pilot Project (WWMPP) Using Two Approaches: Traditional Statistics and Ensemble Modeling. Journal of Applied Meteorology and Climatology, 57(11), 2639-2660. Doi: 10.1175/JAMC-D-170335.1

Seto, T.H., Sutrisno., Tikno, S., Widodo, F.H. (2013). Pemanfaatan Teknologi Modifikasi Cuaca untuk Redistribusi Curah Hujan dalam Rangka Tanggap Darurat Banjir di Provinsi DKI Jakarta dan Sekitarnya. Jurnal Sains \& Teknologi Modifikasi Cuaca, 14(1), 1-11. doi: 10.29122/jstmc.v14i1.2676

Silverman, B.A. (2010). An Evaluation of Eleven Operational Cloud Seeding Programs in the Watersheds of the Sierra Nevada Mountains. Atmospheric Research, 97(4), 526-539. doi: 10.1016/j.atmosres.2010.06.013 